\title{
The Possible Ways of Country Brand Communication and Their Classification Based on the POE Model
}

\author{
Árpád PAPP-VÁRY \\ Budapest Metropolitan University, Hungary \\ e-mail: apappvary@metropolitan.hu \\ Máté FARKAS \\ One on One Communications, Hungary \\ e-mail: mate.farkas@oneonone.hu
}

\begin{abstract}
The number of marketing communications tools and channels is steadily increasing - in addition, this growth has been accelerated since the emergence of the Internet and social media. On the one hand, there is an increasing dilemma of which tools one should choose from the plentiful options, and, on the other hand, the (material, human, and time) resources devoted to this are limited. This is valid for the marketing communications of "classic" products, services, and countries. This review article attempts to present the variety of available options with the help of the POE (paid, owned, earned) model and describe their advantages and disadvantages. The novelty of the study is that it focuses on a review of country communication campaigns and initiatives. It offers various visual examples for the different components of the POE model, clarifying the paid media, owned media, and earned media options for country brand communication. It mostly uses examples from Hungary, but other countries' good practices are also included. Finally, as a result of the analysis, the article summarizes the possible ways of country brand communication according to the POE model in a summary table, which may also contribute to the work of academics and practitioners in the field.
\end{abstract}

Keywords: country branding, country image, marketing communications, POE model

\section{Introduction: The Essence of the POE Model}

Several platforms are available nowadays for enterprises and organizations to communicate themselves. Moreover, the range of tools is so wide that makes it increasingly difficult to choose from - especially since the emergence of the Internet and social media. In addition, this toolkit is expanding rapidly, and 
brand new platforms may appear within a couple of years (Fehér, 2016; Rekettye Jr., 2016, 2017; Józsa-Rekettye Jr., 2015). Nevertheless, the (material, human, and time) resources that can be devoted to marketing communications are limited, wherefore the contents of the so-called media mix - that is, the elements that are most favourable regarding cost and benefit - must be considered carefully. First of all, this requires the understanding of how these tools may be grouped and what their advantages are.

The most popular, albeit somewhat outdated, approach of marketing communication channels is the classic ATL (above the line) and BTL (below the line) classification, which has been supplemented by the TTL (through the line) format after a while. These together have been the foundation of the frequently used term integrated marketing communications, which can be interpreted as a framework considering all communication tools as a whole.

However, a better and more modern way of classification that may be used is the so-called POE model (Corcoran, 2009), which has been mentioned in an increasing number of marketing textbooks in Hungarian (Horváth-Nyirő-Csordás, 2013; Bauer-Horváth, 2013; Rekettye-Törőcsik-Hetesi, 2015; Keszey-Gyulavári, 2016; Kenesei-Cserdi, 2018). The meaning of the three letters of POE is:

- Paid media: Paid platforms are excellent tools for promotion and attracting traffic directly to our owned tools. In a traditional approach, all media platforms that are paid by the company belong here; for example: TV advertisements, radio spots, print advertisements, an Internet display campaign, or any other online advertisement.

- Owned media: All platforms that are in control of the brand owner and belong to the brand. One of the most frequently used examples is a brand's own website, but these also include the social media pages managed by the brand. Classic tools of owned media include the brand's own print magazine or merchandizing.

- Earned (or acquired) media: If owned media pages are the "targets", paid media is accompanied by earned media as the other "vehicle" taking people there. On the one hand, this is online word of mouth, which spreads virally in the form of mentions, shares, recommendations, likes, and comments. On the other hand, this includes press publicity with journalists writing about us.

In the following chapters, we use the POE model to examine and classify communication tools that can be used for country branding. In brief, country branding is actually nothing else than the technical application of branding for countries in order to improve the reputation of the country, thus resulting in greater competitiveness (Papp-Váry, 2019). In addition, this must be carried out in increasing competition, which is fuelled by the increasing number of countries, globalization, and digitalization. The most tangible part of country branding is the stimulation of tourism, but the attraction of investors, the development of export for products originating from the country, and - in general - the development of 
country reputation also belongs here. Therefore, the application of appropriate marketing communication tools is an important part of the branding process. The summary provided by the article may thus fill a gap, exploring each possibility using the POE model. In addition to companies, the use of this novel approach may also be useful for countries because there are much more limitations in the case of the classic ATL/BTL division, and in many respects it urges us to spend the budget on tools that reach many people but are expensive as well. At the same time, we must also add that this presentation of the POE cannot be comprehensive, but the next couple of pages may indicate the plethora of options to deliver the message. The article uses mostly examples from Hungary, but other countries' good practices are also included.

\section{Paid Country Branding Tools}

\section{Outdoor Advertising}

Paid country branding tools can be divided into two levels: offline and online solutions. One of the most classic advertisement formats from the first group is outdoor advertising: billboards, city lights, and other outdoor or indoor solutions. Hungary is an example for the use of such tools, and not exclusively for tourism purposes: on the $50^{\text {th }}$ anniversary of the 1956 revolution, in 2006, the central advertising platforms of Times Square in New York City featured two billboards with contemporary images of the 1956 revolution (tank, demonstrating citizens) and a key message: "Our revolution was not a movie". NYC Times Square is one of the most crowded public areas with and extremely high advertising fee, but the creative and awareness-raising appearance attracted international media coverage, and the advertising spending may have resulted in multiple return.

\section{Print Advertising in Newspapers and Magazines}

The list of offline tools also includes another classic form of advertising: print advertising. Until the end of the nineties, appearance in foreign newspapers and thematic magazines in the forms of advertising, paid PR articles, or sponsored inserts played an outstanding role in the media mix. Exciting examples include a series of advertisements created by a legendary figure of advertising, David Ogilvy, which contributed to the successful rebranding of Puerto Rico and the rise of tourism, resulting in the restoration of regional economy. 


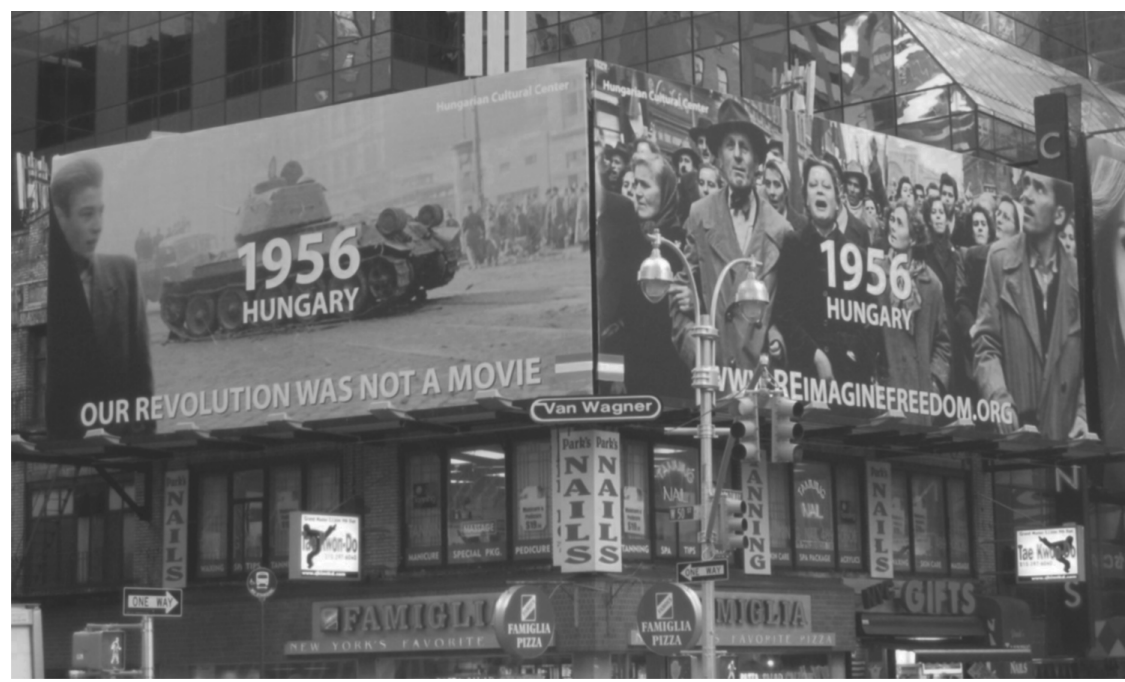

Source: Eszter Hargitai, http://www.flickriver.com/photos/eszter/tags/1956/, retrieved on: 31 July 2018

Illustration 1. Outdoor advertising works best when it stands out of the crowd

- as the billboards at Times Square did on the 50 ${ }^{\text {th }}$ anniversary of the 1956 revolution

Pablo Casals is coming home - to Puerto Rico
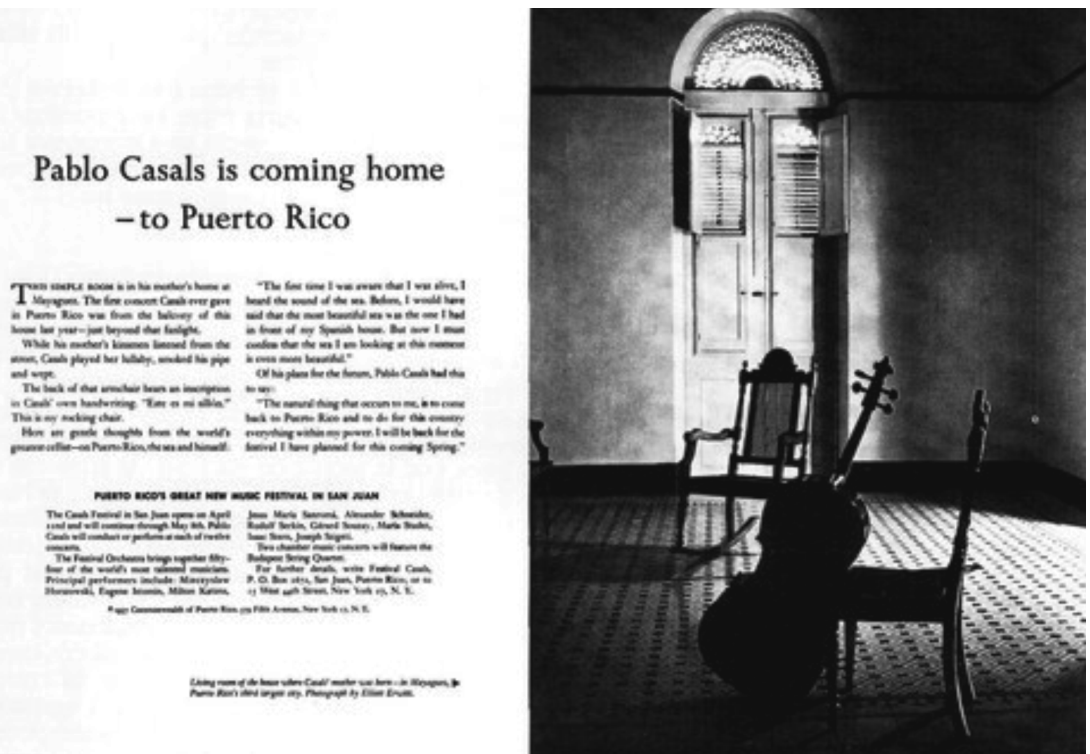

Source: http://alumnos.unir.net/carlosalbertopascual/files/2015/05/puerto-rico-ogilvyReasonWhy.es_.jpeg, retrieved on: 31 July 2018

Illustration 2. The campaign created by the legendary David Ogilvy played an important role in the rebranding of Puerto Rico and boosting the number of tourists 
However, that was back in 1958, the prestige of newspapers was outstanding, and they played some kind of an opinion leader role, impacting public opinion to a much greater extent. From today's perspective, the most surprising fact may be that people looked at newspaper advertisements and even read them (Ogilvy, 2001). Today's situation is quite different though: people skip through advertisements placed in newspapers, and PR articles clearly "show" that they are sponsored contents moreover, why would we read a piece about a country which we have not heard of or have only heard bad news about? According to research reports, these articles are mostly read as a kind of affirmation by people who have already visited the country. In addition, if the financial resources are only sufficient for one placement of this kind, it is not worth spending the money on this. It may still be functional in a series format (as in Ogilvy's case), but it is likely to fail as a stand-alone advertisement.

\section{Television Advertising}

Television advertisements have been "buried" for several years as a result of the expansion of online marketing and social media, but they continue to prosper, playing a significant role in the media mix of large enterprises, especially FMCG and pharmaceutical companies. Nevertheless, countries may also use it (and they do use it): the "country image film" often plays a central role in the branding process. The greatest advantage of television advertisements is that they affect multiple sensory organs at the same time. Attention can be grabbed with visuals and sounds, and this attention may be maintained if the content is relevant and entertaining. Moreover, if the advertisement is attractive and aired frequently enough on the appropriate television channel, it may also be mentioned by people, which may increase the awareness of the country and attract tourists, but one should not expect a considerable image change from a television advertisement.

In spite of several advantages of television advertising, calculations are often wrong in practice. On the one hand, the creation of 30-60-second spots are a tough challenge as the promise of a country must be condensed in this amount of time. On the other hand, it is often almost impossible to figure out the country promoted by the advertisement as a result of cliché messages and similar images and scenes. This is because most such spots are created according to the following storyline: smiling family, maybe a young couple, an airplane is landing (look, we have an airport!), chemists in white gowns (look, we have science!), catering establishments (look, you can eat and drink here!), night traffic with flashing lights in a time-lapse sequence (look, we have cars!). These films tend to be so similar that wiser countries put their name or tourism logo in a corner of the screen during the whole length of the spot to distinguish themselves.

Besides the content, it is also important to put special emphasis on media buying - why would countries produce expensive films if they do not reach 
the appropriate recipients? However, country brand advertisements often fail to appear in a priority time slot, and one can see them on Eurosport in daytime (during work hours) on weekdays, for example. But are the people with appropriate purchasing power at home during these time slots?

In order to measure the effectiveness of television advertisements, it may be helpful to insert a landing web page or hashtag in the advertisement, providing access to more information about the country. This way, countries may measure how many people became interested as a result of the film.

\section{Paid Online Presence}

A wide range of online marketing tools is available nowadays. In addition to (or instead of) classic banner advertisements, so-called rich media solutions have become part of the palette. These can also be considered as the successors of magazine advertisements, where the effectiveness of the small display formats embedded in the articles or the large ones placed on the main page primarily depends on the level of attractiveness, mobilization, and activization of the specific creative appearance and the message included as well as the specific medium's coverage of the target group.

The marketing tool developing the coverage of the target group to a high degree of perfection is social media, in particular Facebook and Instagram. Geotargeting is also functioning in the planning of a Facebook campaign - therefore, several countries strive to display their sponsored social media contents and advertisements in the language of the specific target country. These also include so-called pre-roll YouTube advertisements that are paid. We may often see country image films or country advertisements before contents published on the largest video-sharing website with millions or billions of views.

\section{Owned Media Platforms for Country Branding}

\section{Website}

As already mentioned, this kind of owned media primarily means the website (or, more specifically, websites). Not only has Austria's slogan been translated into 22 languages, but their websites are also available in the same number of languages. Several countries differentiate their websites according to specific aims, maintaining separate websites for the promotion of tourism (visit _country name_), investment (invest in _country name_), and domestic tourism. Centrally edited websites play a very important role: they provide a compass for marketing communications, provide assistance for the measurement of campaign results 
(visitor number, composition, etc.) as a landing page, and serve as the most important online contact point. Therefore, the creation of a good website is a key question: the consistent messages placed there provide motivation for incoming tourism and important information during the stay. Examples include the tourism websites of Finland and Australia: their "plan your trip" function even provides help in planning the trip and various programmes.

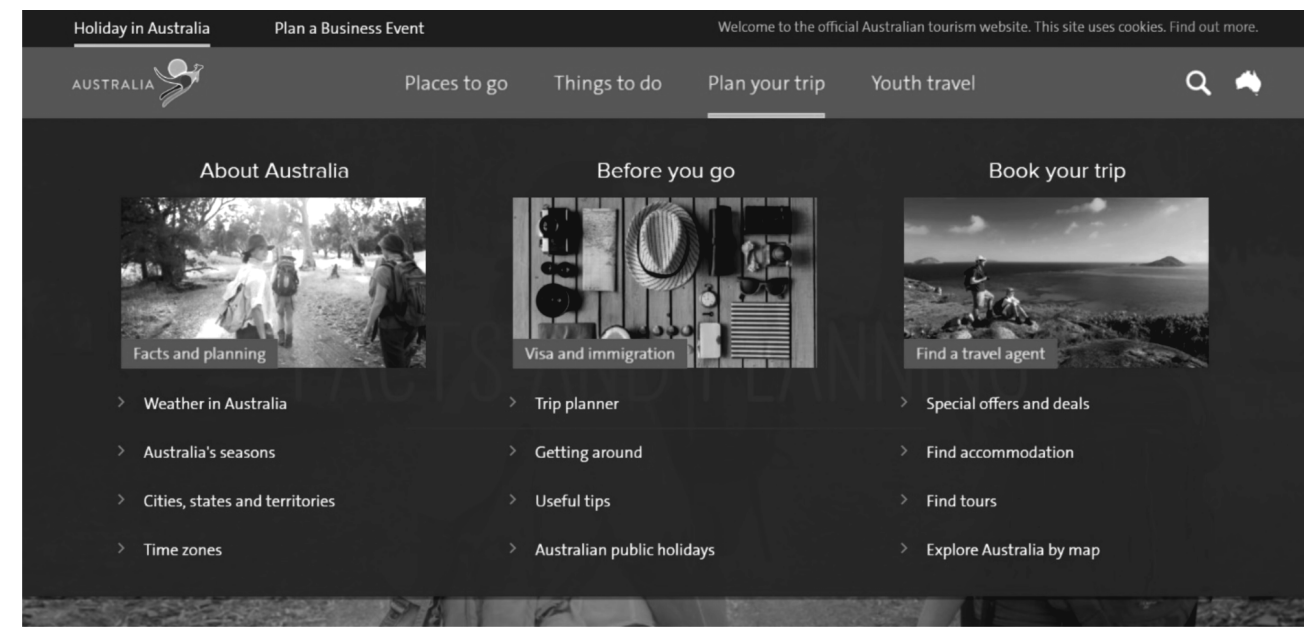

Source: https://www.australia.com/en/facts-and-planning.html, retrieved on: 31 July 2018

Illustration 3. An increasing number of country websites have a "Plan your trip" function, and Australia's website is one of them

\section{Own Social Media Profiles}

Besides websites, the management of own social media profiles is also a key issue (Klausz, 2016). Nowadays, social media channels do not only play an important role in reaching the young generation but are also used by older people on a daily basis. In addition to websites, Facebook pages also fulfil multiple functions: they are information hubs providing the greatest amount of relevant basic information on the country, useful links, and further subpages, but they also include entertaining contents to maintain interest.

We may also mention another interesting aspect: in addition to convincing tourists or investors, social media plays an increasingly significant role in diplomacy. Although the world press is presently abuzz with the tweets of US President Donald Trump, the first highly successful e-diplomacy programme was launched during the presidency of Barack Obama. During that period, Secretary of State Hillary Clinton started a comprehensive and extensive initiative called

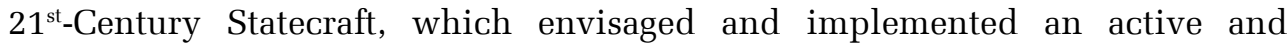
organized social media presence of the administration. This is especially true 
for the employees of the US Department of State and delegations. In practice, the measure involved the creation of 194 different Twitter accounts and 200 Facebook profiles. At the time, the US Department of State employed 200 professionals who only worked on the management of social media, and it is quite likely that the number has increased ever since (Századvég, 2015).

One of the main platforms for the "recycling" of television advertisements is the countries' YouTube pages and similar platforms, including Vimeo. We have already mentioned paid pre-roll advertisements, but a film may also spread by itself (see the section on earned media below). Examples include a Croatian image film with the silver medallist heroes of the 2018 FIFA Football World Cup, other athletes, musicians and actors, resulting in more than 700 thousand views on the "Croatia - Full of Life" YouTube channel.
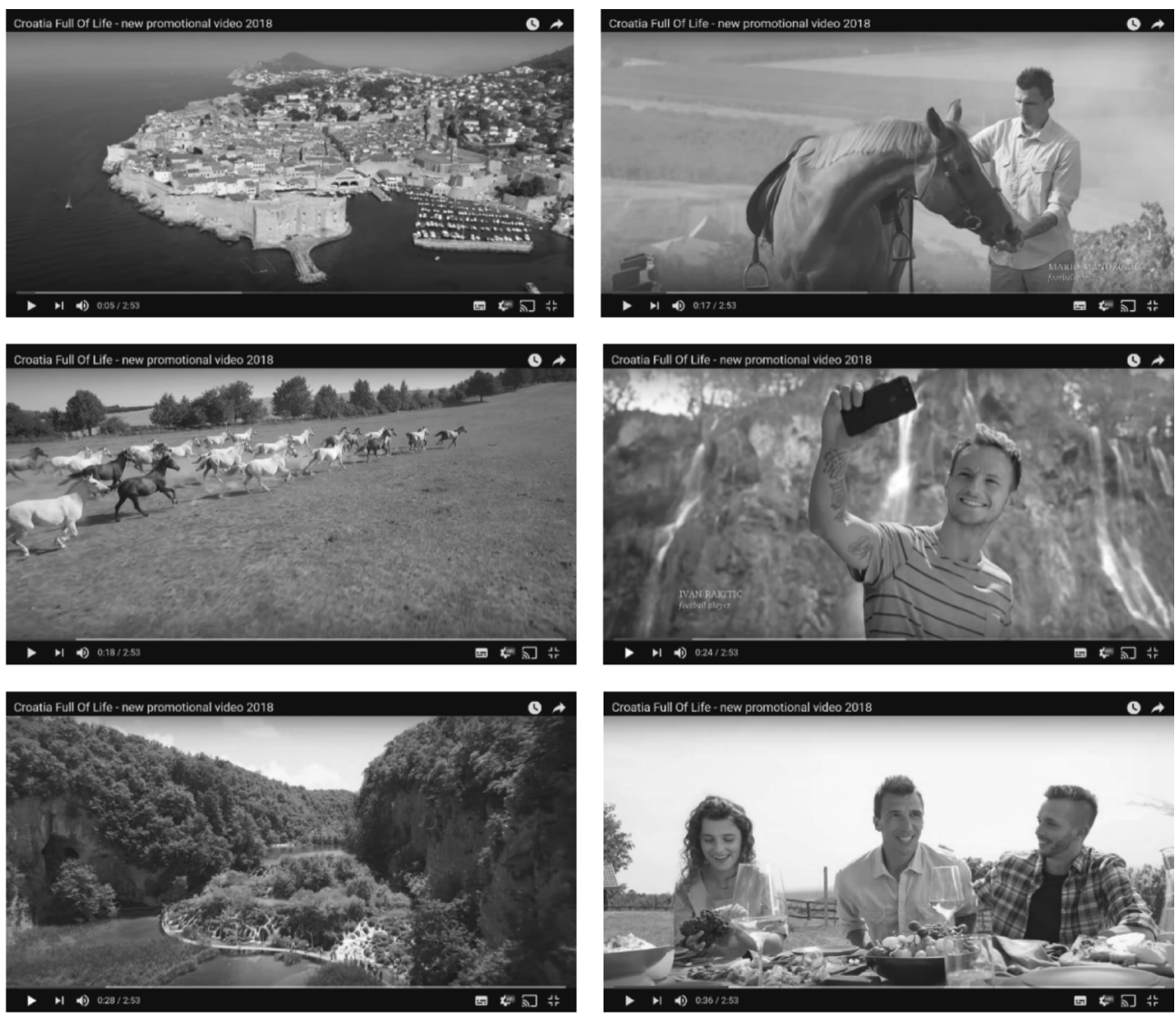

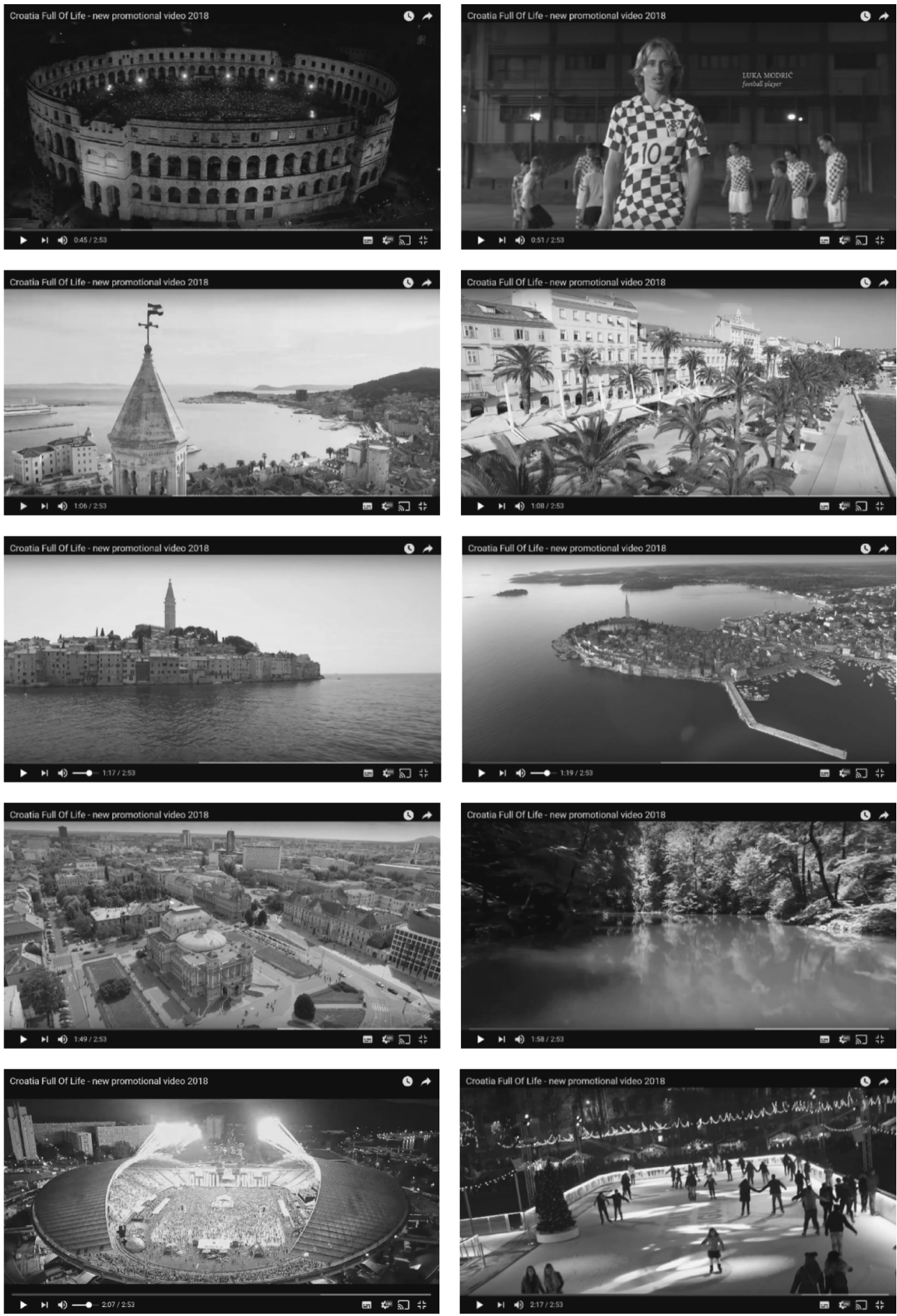

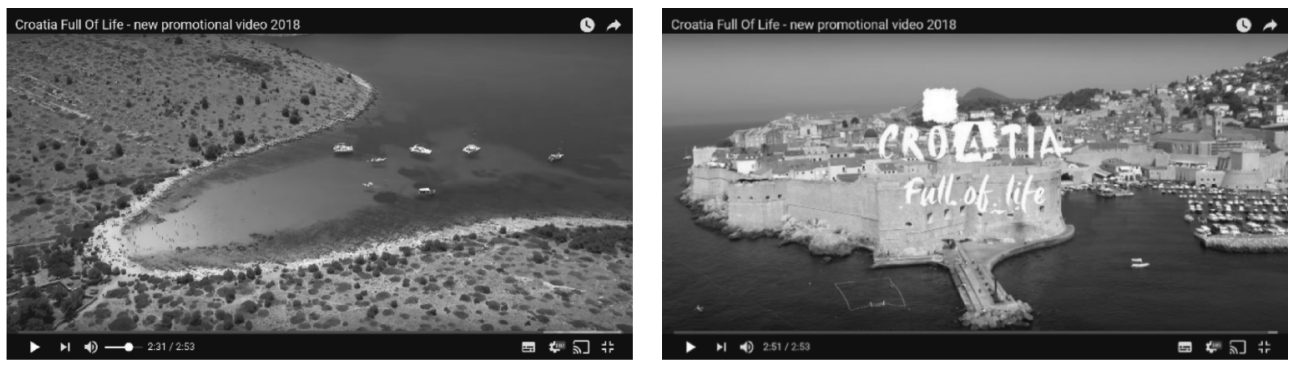

Source: Croatia Full of Life - New promotional video 2018, https://www.youtube.com/ watch?v=0XbIR7e9PYM, published: 7 November 2017, retrieved: 31 July 2018

Illustration 4. Frames from the popular Croatia country image spot, featuring Croatian football players and other celebrities

This tool, that is, a country's own YouTube channel, is only operating successfully if it features a variety of self-produced contents. The Croatians also succeed in this: in addition to short advertising spots, their channel also includes road movies (longer films, each recorded in a specific tourist site), which inform the target group about the available experiences in several parts.

\section{Own Publications}

The intertwining of the online and offline categories is well represented by own publications. Sectoral publications of e.g. investment promotion or tourism that have been distributed in a print format in the past (sometimes sent out by mail) can usually be downloaded in .pdf format from the central or sectoral websites of countries. People interested in a country receive shorter or longer brochures that are available not only in multiple languages offline but also in the form of online direct mail.

\section{Billboards, City Light Advertisements at the Airport}

It is interesting that billboard/city light/outdoor advertising may also be interpreted as an owned media platform, although they do not necessarily belong there in a technical sense. We may often see such materials of variable quality and reason, for example, at airports, by the baggage carousel, or on roads to and from the airport.

\section{Merchandizing Tools, Souvenirs}

Pens, notepads, T-shirts, and caps are also representatives of the owned category. However, in a broader sense, souvenirs may also be listed in this category, 
although it is not easy to affect their quality at a national level. It is possible to impose regulations, but how can you check their implementation? Nevertheless, there are good grassroots initiatives in Hungary in order to improve the quality of souvenirs, e.g. Memories of Hungary (see Papp-Váry-Szatmári 2011).

\section{Events}

Events are one of the most complex tools of marketing communications, and they are one of the tools that can achieve the most aims at the same time. In terms of country branding, we must highlight the so-called mega-events, whose two "kings" are the Olympics and the Football World Cup, but we may also mention the Formula 1 Grand Prix weekend. It is no coincidence that Hungary decided to build its first significant tennis complex on Margaret Island because a Grand Slam or ATP 1000 tennis tournament attracts both stars and sports media attention for several weeks. In terms of image, the key factor is generating media attention: the return of organization costs is usually shown in marketing value as many foreigners get to know or identify smaller countries through these events. At the same time, one should not expect a development of country image from individual events of this kind - research shows that Brazil's image actually declined after the 2014 Football World Cup and the 2016 Olympics in Rio (Anholt, 2016). What was the reason? Well, it was not the weakness of organizing, but the fact that once international media crews were in the country, they did not only cover the event itself but also the whole city and country, and their coverage also included poverty, poor public safety, prostitution, drug dealers, and gangs.

In this regard, it may be more practical not to put all your eggs in one basket but organize smaller events (that are still big enough in their own category) on a yearly basis. It is no coincidence that thanks to Sziget Festival the first spontaneous association of young foreigners linked to Hungary is Sziget. Nevertheless, Hungary's image may be improved in a similar way through organizing professional events and conferences in the country regularly or creating events like Brain Bar. The most important point is creativity, insomuch that there are authors who use the term creative event management or experience organizing instead of event organizing in this context (Dér, 2013, 2017).

\section{Earned Media Platforms}

Although events themselves can be considered own media platforms, the media presence generated by them is considered earned media. Such publicity is always more important than information promoted through advertising, that is, paid media, because people are always suspicious of the latter and tend not to believe it. 


\section{Public Relations, Press Relations}

As a result, the importance of public relations (PR) activities preparing publicity has increased significantly in the past decades. A book on the topic, titled The Fall of Advertising $\&$ The Rise of PR, had already been published in 2002 (Ries-Ries, 2002). PR professionals know that good content, a good story is one of the strongest motivations. The key figures primarily targeted by PR activity are journalists, representatives of the press, who can produce quality materials in their field credibly to professionally present the country's advantages, attractions, and experience promises. Examples include Finland's National Media Centre dedicated to this purpose, which not only monitors and analyses media appearances about Finland regularly or provides a large free photo bank of the country but takes the service of foreign journalists very seriously. For example, they organize so-called study tours, that is, press visits together with relevant institutions, which may be several days long. However, the role of the National Media Centre is not repetitive persuasion: they "only" provide appropriate professional circumstances for the journalists, help them organize their trips, link them with the appropriate contact persons, and are available for any kind of help. As a consequence, the materials produced this way will be unique and valuable pieces and will not be teeming with bad advertising panels - and the personal experience or impression of the journalist, TV reporter, or online correspondent is a more important reference point for the receiver than any TV sport or sponsored content.

\section{Buzz, Word of Mouth}

Of course, centrally managed campaigns can also be successful, and the number of shares has become one of their most important indicators. Organic spread usually develops if the content can address the target group emotionally, and the consumers recommend or forward it to their contacts. In the online space, this is called buzz, and in the offline world its name is word of mouth. Ideas have a key role here - examples from the corporate sphere include Red Bull, a brand with regular unique creations. Just think about Felix Baumgartner's stratosphere jump, which was followed live by millions of people on the company's media platforms. Elon Musk's campaign with a Tesla Roadster shot into space was also a similar activity. Countries do not necessarily need to consider global activities of this calibre, but creativity is a vital question for smaller nations. Innovative activities attracting attention, such as the "Best Job in the World" launched by Tourism Queensland, can be successful on a tight budget. 


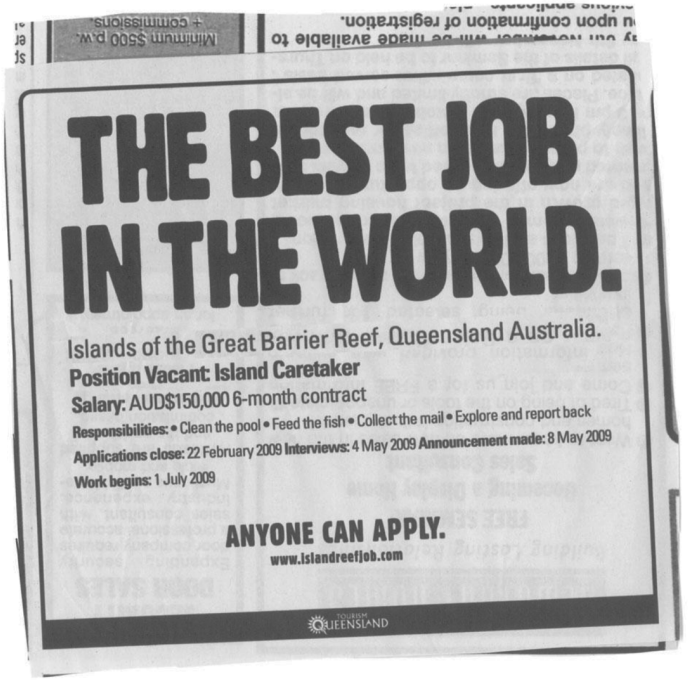

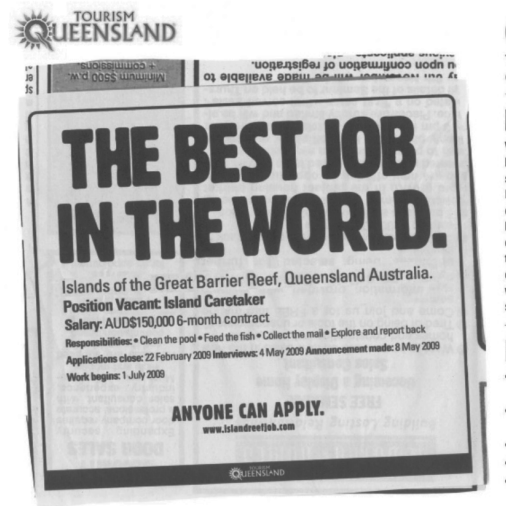

\section{Objective} the Great Barrier Reef.

\section{Idea}

We created The Best Job in the Worto First-hand accounts from online sources are highly influential, so the Istands Caretaker will spend six-month hack throug blogs photeporing diaries. We placed simple recriitentent through online recritument sites, directing traffic to islandreeffob.con with further engagement through social networking sites.

\section{Results}

- More than SUS100M worth of media coverage (trom a budget of susi.2m - In 56 days islandreefijob had 34 (a) 1 countries 450,000 oniline votes for the Wilo 231,355 blog entries
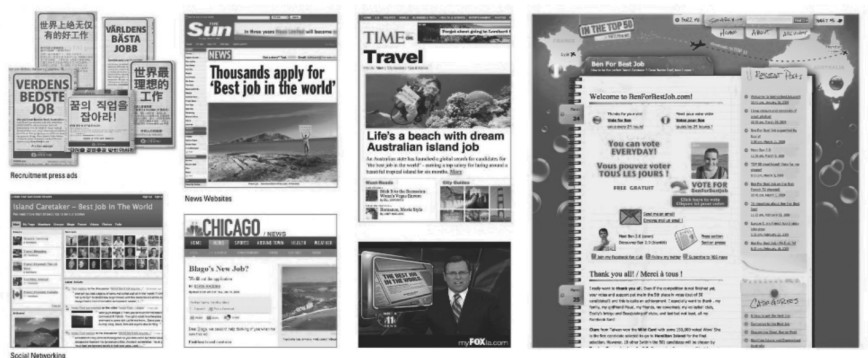
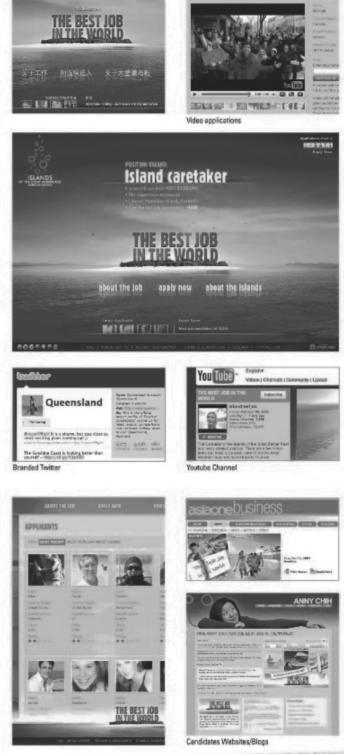

Achieving worlduide awareness of the Islands Act cont Barier Beef. And creating desire for the unique experiences available there.

Sources: https://www.adsoftheworld.com/media/print/tourism_queensland_best_job_in_the_ world, published on: 12 February 2009, retrieved on: 31 July 2018; http://www.adeevee.com/ aimages/200910/01/tourism-queensland-great-barrier-reef-the-best-job-in-the-world-media-30893adeevee.jpg, published on: 1 October 2009, retrieved on: 31 July 2018

Illustration 5. The "Best Job in the World" campaign well demonstrates how a destination can generate word of mouth or online buzz 


\section{Installations}

Many people would associate word of mouth or buzz with new solutions, but it is also true in the case of classic tools that good advertisements are ones that generate word of mouth or buzz. This can be achieved through simple things such as an outdoor installation. The Budapest installation created at Heroes' Square in Budapest, for example, serves as a location for many selfies and group pictures - it is no coincidence that many Hungarian cities adopted the idea and installed one with their own names from Miskolc to cities by Lake Balaton. This is also one of the best solutions for a country/city because all people who are contacts or followers of the posting person will know where she/he has been.

\section{Prosumers, Bloggers, Vloggers, Influencers}

The compound term "prosumer" created from the words producer and consumer describes expert consumers, that is, those customers who know a lot about the product (in this case, the country) and are happy to take part in its development. Although convincing a prosumer takes up much more energy or attention, it also has a multiplier effect: it can influence dozens of potential customers towards the favourable direction.

Special figures include so-called travel bloggers, who are travelling influencers, that is, opinion leaders. They have channels developed by themselves (usually YouTube, Instagram, or a blog), their job is travelling, and they report their experiences for their community in the form of a video/picture/article. The difference between a journalist and an influencer is that the former works for the editorial office of a specific medium, while the latter is the medium itself, and the platform of communication is his/her own channel. Furthermore, the difference between prosumer and influencer is that the former is a fan of the brand and does not require financial reward for his/her efforts, while the latter hardly ever influences his/her carefully built fanbase for free because this would risk his/her own livelihood. In this regard, the question is if influencers should appear here or in the category of paid media.

\section{Stars, Celebrities}

Actors/actresses, sportspeople, models, and musicians have long been used effectively in campaigns, and their popularity is worth building on in country branding. The abovementioned Croatian image film, for example, featured several famous footballers, and all of them shared thoughts about their motherland or roots in the video - not in a pushy or bored way but with pride. The influence of stars is also well demonstrated by Will Smith's visit to Hungary: the star's mini- 
video uploaded to Instagram with him dancing and having fun to the music of In My Feelings on top of the Chain Bridge was viewed by 3.3 million people in only 2 weeks. Moreover, a making-of footage was uploaded on YouTube with the name Budapest mentioned several times, also featuring the Danube with the music of Johan Strauss's Blue Danube Waltz. This was viewed by 2.4 million people in two weeks. If we merely look at the numbers, it may be interesting to see a counterexample: the official country image film (more specifically: city image film, as it focuses on Budapest) that had debuted shortly before it was viewed by 35 thousand people on the official Hello Hungary YouTube channel. (We must add that the number of viewers was 88 thousand on the WeLoveBudapest YouTube channel.) In addition, Will Smith published a more than seven minutes long video on the renovation works of the Opera House in Budapest where he had been given a tour. The next day he continued "thematizing Hungary" by sharing his experiences of the Frida Kahlo exhibition in the National Gallery, and earlier he published a Fathers' Day video with the Chain Bridge in the background (My Son PUNCHED Me in the Face), which has been viewed by 5.3 million people on YouTube.

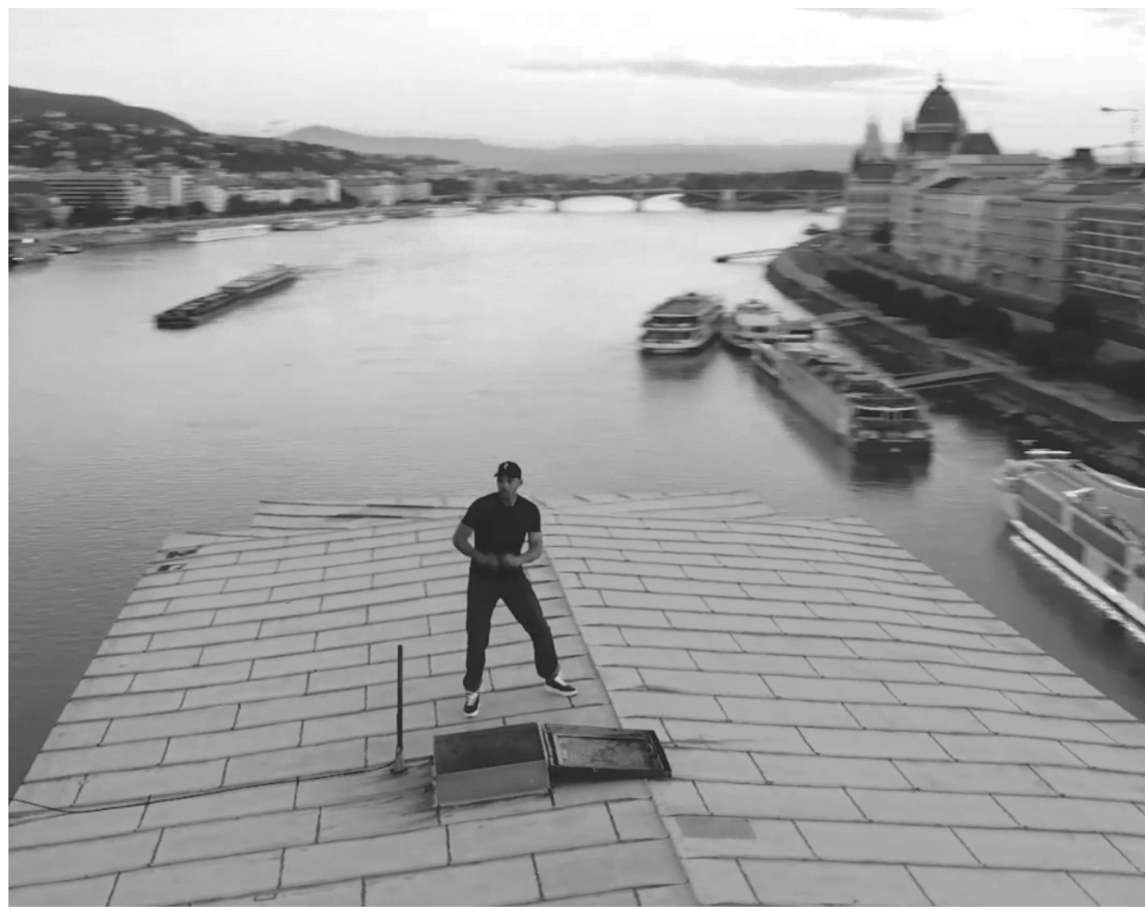

Source: https://welovebudapest.com/en/2018/07/13/video-shows-will-smith-climbing-chainbridge-on-his-last-day-in-budapest/, published on: 13 July 2018, downloaded on: 31 July 2018

Illustration 6. Will Smith is dancing on top of the Budapest Chain Bridge with the Parliament in the background 


\section{Presence in Films and Video Spots}

In the same context, we must also highlight appearances in cinematographic works (Irimiás, 2012, 2015; Papp-Váry, 2009). Thanks to Korda and Origo film studios, Hungary has been featured in an increasing number of Hollywood productions - although Budapest often plays the role of another city, for example, Berlin (see the movies Spy Game or Atomic Blonde), Moscow (Red Heat, Die Hard V, Red Sparrow), Beijing (The Martian), or Rio de Janeiro (Evita). Nevertheless, there are also examples where the title of a movie features Budapest: such is the movie Grand Hotel Budapest, though this movie was not recorded in Budapest but in Berlin. The impact of the movie is still considerable: the authors of this article met a foreign student at Budapest Metropolitan University who applied to the institution because of this movie.

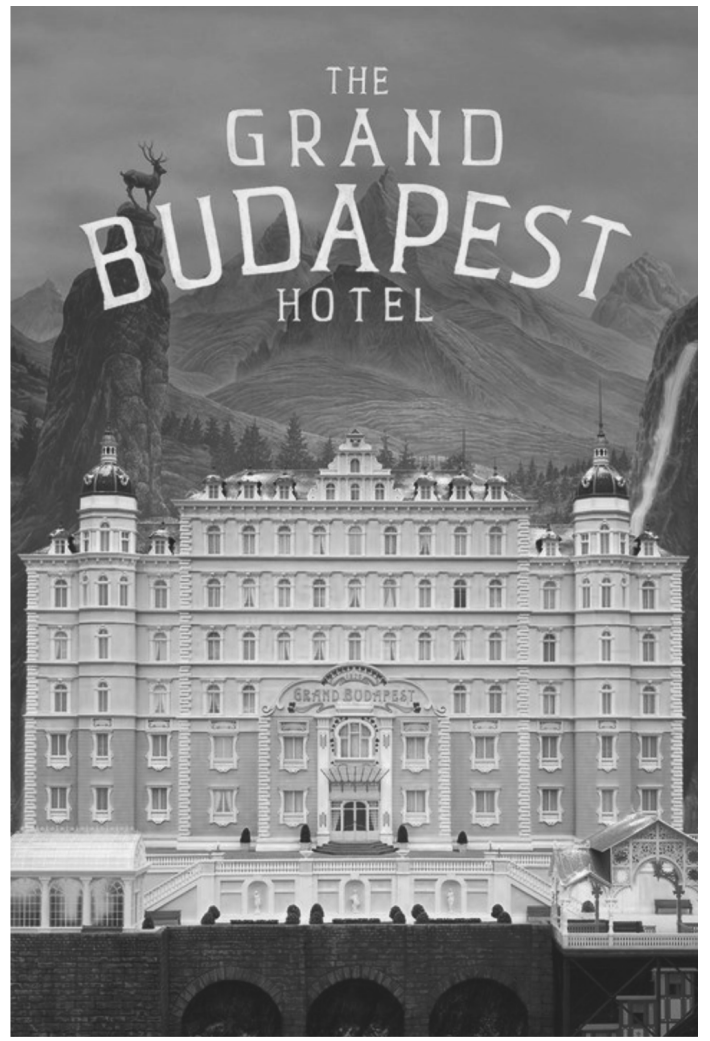

Source: http://www.mrqe.com/movie_reviews/the-grand-budapest-hotel-m100104679, retrieved: 31 July 2018

Illustration 7. The movie The Grand Budapest Hotel was not filmed in Hungary, but it still has an effect on the country brand 
Another activity that may raise attention is if celebrities move to the country for the time of a shooting. Ashton Kutcher and Mila Kunis, for example, spent months in Budapest with their family in 2017, during which they visited the water sports world championships. Workers of the restaurants they visited made selfies with them, and the local and international press followed their steps what they were not always happy about.

Besides movies, appearance in video clips may also affect the brand, whether intentional or not. Budapest also provided the background for the song Fireworks by Katy Perry, and the extra attention generated by the singer worked out pretty good for the Hungarian capital, especially because they showed very beautiful so-called B-rolls of the city - and the video on YouTube has been viewed more than 1.1 billion times! George Ezra's song titled Budapest was viewed by 128 million people in 4 years, although the capital was not featured with images. (An interesting fact: his song called Barcelona was "only" seen by 10 million people.)

\section{Engagement Campaigns}

In addition to prosumers, influencers, and stars, average consumers also like to get involved in the life of brands. The best campaigns are about engagement: they do not only offer something but also request some effort from the consumer, whether it is the uploading of a picture, publishing a hashtag, solving a puzzle, or an adventure with many stages. This characteristic of human nature has been known since Confucius: "I hear and I forget. I see and I remember. I do and I understand." Similarly, to education, two-directional, active, wide-ranging cooperation is much more successful in marketing communications than onedirectional communication.

\section{Forums, Applications}

Opinions placed on forums and travel advisory pages or rankings shared via applications (e.g. TripAdvisor) play a significant role in decision-making, and - although sometimes their origin is doubtful - they often have a bigger influence on an opinion about a country or pre-vacation decision-making than any travel bureau prospectus. The advance of artificial intelligence has not left the travel market cold: Hopper is one of the world's hottest application projects today, which can plan and predict the vacation closest to the user at the best price possible. The idea that a machine knows better what kind of vacation/trip a human needs sounds unbelievable at first - it is limited to air tickets, dates, and hotel reservations at the moment -, but the founders could drum up 84 million dollars for the further development of the application and international expansion; therefore, we will probably hear more about it in the future. 


\section{Guerrilla Activities, Media Hacks, Viral Films, Consumer- Generated Content}

Credibility is not based on centrally selected message systems that are set "as accurately as chemists' balances". Guerrilla activities, media hacks, and viral films can be just as important because viral spread is brought about by the consumers, and there is no need to pay large amounts of media-buying fees - in addition, as they are grassroots-type activities (or, more specifically, they often only seem to be that), they are less suspicious. The next level of viral videos is consumergenerated content, when the consumer itself is the creator of the content. Here we may think of vacation pictures of beautiful landscapes, but this tool is not at all seasonal. Groups of attractions, cities, or even countries may advertise activities linked to them based on the contents generated by the consumers. Croatia, for example, reached more than 50 million people in its latest campaign of this kind. During the Epic Week in Croatia activity, people could plan their dream vacation according to the 218 activities published centrally. Their only task was to create a realizable selection and provide reasons of their choice for each selected activity. The winner with the best arguments was a British woman called Sophia, who could make her dream vacation in Croatia come true. We can see from the example that almost all tools presented above were used in the campaign: the engagement of the consumer, her efforts, and storytelling.

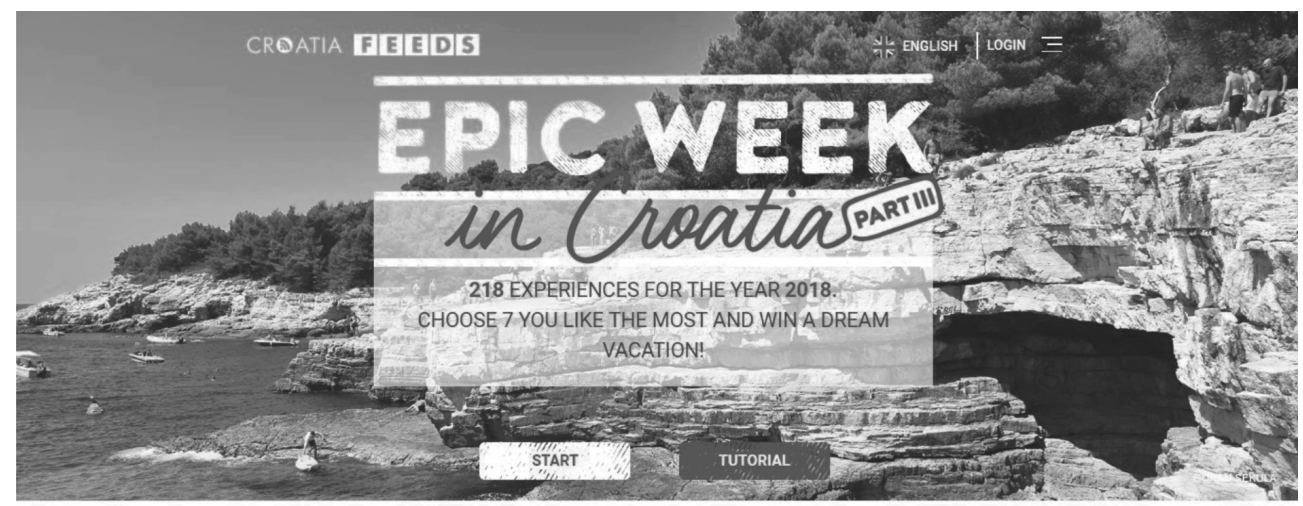

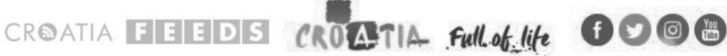

Source: http://hrturizam.hr/kampanja-epic-week-in-croatia-ostvarila-doseg-od-50-milijuna-ljudi/

Illustration 8. Epic Week in Croatia is a good example of an engagement campaign and customer-generated content solutions 


\section{Results: The Classification of Marketing Communication Tools Supporting Country Branding According to the POE Principle}

After our incomplete but comprehensive overview, it is worth creating a table summarizing the variety of communication tools and media a country may use for the building of its brand or the communication of its messages. The table below follows the POE classification described above and places elements accordingly, supplemented with a few other tools that have not been presented. We hope that this classification will help the work of all organizations and professionals involved in country branding, providing them with both theoretical and practical value.

Table 1. A classification of marketing communication tools and media that can be used in country branding, based on the POE model

\begin{tabular}{|c|c|c|c|}
\hline $\begin{array}{l}\text { Nature of } \\
\text { channel }\end{array}$ & Paid & Owned & Earned \\
\hline Traditional & $\begin{array}{l}\text { TV advertisement } \\
\text { Radio advertisement } \\
\text { Outdoor advertisements } \\
\text { Movie advertisements } \\
\text { Press advertisements } \\
\text { PR article / video/radio } \\
\text { interview }\end{array}$ & $\begin{array}{l}\text { Brochures, } \\
\text { prospectuses, brand } \\
\text { magazines } \\
\text { Print newsletter } \\
\text { Customer service/ } \\
\text { customer relationship } \\
\text { Flyer } \\
\text { Postal DM mail } \\
\text { (Mega)event organizing } \\
\text { Merchandizing }\end{array}$ & $\begin{array}{l}\text { PR appearances, } \\
\text { publicity } \\
\text { Study tour } \\
\text { Word-of-mouth } \\
\text { marketing } \\
\text { Recommendation } \\
\text { Appearances in films or } \\
\text { video clips } \\
\text { Sponsorship }\end{array}$ \\
\hline Online & $\begin{array}{l}\text { Search advertisements } \\
\text { Rich media solutions } \\
\text { Facebook advertising } \\
\text { Google advertising } \\
\text { LinkedIn advertising } \\
\text { Instagram advertising } \\
\text { Twitter advertising } \\
\text { E-target and } \\
\text { remarketing } \\
\text { Mobile advertisements } \\
\text { Pre-roll advertisements } \\
\text { Geotargeting } \\
\text { The creation and } \\
\text { advertisement of } \\
\text { applications } \\
\end{array}$ & $\begin{array}{l}\text { Website } \\
\text { Microsite } \\
\text { Electronic newsletter } \\
\text { Online brochures and } \\
\text { prospectuses } \\
\text { Social platforms } \\
\text { (Facebook, Instagram, } \\
\text { YouTube, Twitter) } \\
\text { Search engine } \\
\text { optimization } \\
\text { Blog } \\
\text { Podcast } \\
\text { Newsletter }\end{array}$ & $\begin{array}{l}\text { Online PR appearances } \\
\text { Study tour } \\
\text { Shares, comments, } \\
\text { check-in, online word } \\
\text { of mouth (buzz) } \\
\text { Consumer-generated } \\
\text { content } \\
\text { Guerrilla marketing } \\
\text { tools } \\
\text { Viral videos } \\
\text { User reviews } \\
\text { Media hack } \\
\text { Influencer/star solutions } \\
\text { Prosumer solutions }\end{array}$ \\
\hline
\end{tabular}

Source: A classification of countries by the authors of the article, based on Bálint Hinora, 2016. Marketingkommunikációs eszközök bemutatása és használatuk I-II. rész (The Presentation and Use of Marketing Communication Tools, Parts I-II), KKV Akadémia (SME Academy) by the Hungarian 
The advantages of the table include that each tool can be easily placed in it which is also important because the number of marketing communication tools (especially in the case of online tools) is increasing daily. The other important advantage of the system is that it highlights the fact that all countries have their own (owned) tools, and they may be the most authentic "news sources" as well. Therefore, the role of paid tools is to divert attention to owned tools. As the article proves, the real value is earned media, including international media coverage of the country and word of mouth in the online space. However, this can only be achieved through more specific, more customized solutions as it is getting harder to reach the threshold.

The difficulty of the model's application is that we may only see centralized country branding in the case of a few countries. Usually, there are separate organizations for the stimulation of tourism, the attraction of investments, or a greater role in diplomacy. This makes sense in many respects; the reason of the problem is mostly that in many cases there is a lack of coordination between these organizations. Therefore, it may be useful for these organizations to think about their marketing communication activities individually in accordance with the POE model. The result is a common platform, a common language that is already available when these organizations coordinate their efforts, significantly improving the country branding process and its successfulness.

\section{References}

Anholt, S. (2016). A nagy országmárka svindli [The Great Country Brand Swindle]. HUG - Hungarian Geopolitics Magazine 1(1): 132-149, <https://issuu.com/ pageo/docs/hug_online_marcius_boritoval_> (accessed on: 1 July 2017).

Bauer, A.-Horváth, D. (eds.). (2013). Marketingkommunikáció: Stratégia, új média, fogyasztói részvétel [Marketing Communication: Strategy, New Media, Consumer Participation]. Budapest: Akadémiai.

Corcoran, S. (2009). No Media Should Stand Alone: An Empowered Report. Defining the Roles of Owned, Earned and Paid Media in Online Marketing. Forrester Report. <https://www.forrester.com/report/ No+Media+Should+Stand+Alone/-/E-> (accessed on: 1 July 2017).

Dér, Cs. D. (2013). Kreatív eseménymenedzsment [Creative Event Management]. Budapest: Arts and Business Kft. (2017). Élményszervezés és -menedzsment [Event Planning and Management]. Budapest: Arts and Business Kft. 
Fehér, K. (2016). Digitalizáció és új média - Trendek, stratégiák, illusztrációk [Digitalization and New Media - Trends, Strategies, and Illustrations]. Budapest: Akadémiai.

Hinora, B. (2016). Marketingkommunikációs eszközök bemutatása és használatuk [The Presentation and Use of Marketing Communication Tools]. Budapest: Magyar Marketing Szövetség - KKV Akadémia.

Horváth, D.-Nyirő, N.-Csordás, T. (eds.). (2013). Médiaismeret: Reklámeszközök és reklámhordozók [Media Studies: Advertising Tools and Advertising Media]. Budapest: Akadémiai.

Irimiás, A. (2015). Filmturizmus: A filmek és televíziós sorozatok turisztikai szerepének és hatásainak geográfiai vizsgálata [Film Tourism: A Geographical Examination of the Role and Effects of Films and Television Series in Tourism]. Budapest: Akadémiai.

Józsa, L.-Rekettye Jr., G. (2015). International Research on the Future of Marketing Communication. In: Hunter, M. (ed.), Annual International Conference on Enterprise Marketing and Globalization: $4^{\text {th }}$ Enterprise Marketing and Globalization (EMG 2015) Conference. 15 December 2015, Singapore: Global Science and Technology Forum, 13-18.

Kenesei, Zs.-Cserdi, Zs. H. (2018). Szolgáltatásmarketing a turizmusban [Service Marketing in Tourism]. Budapest: Akadémiai.

Keszey, T.-Gyulavári, T. (2016). Marketingtervezés [Marketing Planning]. Budapest: Akadémiai.

Klausz, M. (2016). A közösségi média nagykönyve - Hogyan vidd sikerre céged és önmagad [Book of Social Media - How to Be Successful with Your Company and Yourself]. Budapest: Athenaeum.

Ogilvy, D. (2001). Ogilvy a reklámról [Ogilvy on Advertising]. Budapest: Park. Papp-Váry, Á. (2009). Országimázs a moziban [Country Image in the Movies]. Marketing \& Media, 14(9): 13-26.

(2019). Országmárkázás - Versenyképes identitás és imázs teremtése [Country Branding - Creating Marketable Identity and Image]. Budapest: Akadémiai.

Papp-Váry, Á.-Szatmári, B. (2011). Újragondolt szuvenírek [Revised Souvenirs]. Marketing \& Média, 16(4): 16-17.

Rekettye, G.-Törőcsik, M.-Hetesi, E. (2015). Bevezetés a marketingbe [An Introduction to Marketing]. Budapest: Akadémiai.

Rekettye Jr., G. (2016). A következő évtized marketingkommunikációja egy nemzetközi kutatás eredményei [The Marketing Communications of the Upcoming Decade - The Findings of an International Research]. Vezetéstudomány 47(3): 12-22. 
(2017). The Future Performance of Marketing Communication - A Comparative Study. International Journal of Business Performance Management (IJBPM) 18(3): 293-306.

Ries, A.-Ries, L. (2002). The Fall of Advertising \& The Rise of PR. New York: HarperCollins Publishers Inc.

Századvég. 2015. Public diplomacy stratégiák [Public Diplomacy Strategies]. $<$ https://szazadveg.hu/uploads/media/587ceed607ef2/public-diplomacystrat.pdf $>$ (accessed on: 20 January 2018). 